5. Кримець, Л. В. Філософські аспекти влади в управлінні науково-освітнім простором [Текст]: монографія / Л. В. Кримець. - К.: Золоті ворота, 2015. - 383 с.

6. Крымец, Л. В. Социальное взаимодействие в контексте постиндустриального общества на современном этапе развития [Текст]: монографія / Л. В. Крымец. Saarbrucken, Germany: Lap Lambert Academic Publishing, 2012. - $163 \mathrm{c}$.

\section{References}

1. Gabermas, Ju. (2011). Posmetafizichne mislennja. Filosofija osviti, 1-2, 41
2. Fuko, M. (1996). Volja k istine: po tu storonu znanija, vlasti i seksual'nosti. Raboty raznyh let. Moscow: Kastal', 157.

3. Fukujama, F. (1990). Konec istorii. Voprosy filosofii, 3, 134-148.

4. Habermas, Ju. (2000). Moral'noe soznanie i kommunikativnoe dejstvie. Sankt-Peterburg: Nauka, 58.

5. Krimec', L. V. (2015). Filosofs'ki aspekti vladi v upravlinni naukovo-osvitnim prostorom. Kyiv: Zoloti vorota, 383.

6. Krymec, L. V. (2012). Social'noe vzaimodejstvie v kontekste postindustrial'nogo obshhestva na sovremennom jetape razvitija. Saarbrucken, Germany: Lap Lambert Academic Publishing, 163.

Рекомендовано до публікації д-р філос. наук, професор Самчук 3. Ф. Дата надходження рукопису 23.09.2015

Кримець Людмила Володимирівна, кандидат філософських наук, провідний науковий співробітник, Науково-дослідна лабораторія (соціально-гуманітарних проблем), Національний університет оборони України ім. І. Черняховського, пр. Повітрофлотський, 28, м. Київ, Україна, 03049

E-mail: karnall@mail.ru

\title{
УДК: $100+101+354.2$
}

DOI: $10.15587 / 2313-8416.2015 .51194$

\section{СОЦІОКУЛЬТУРНИЙ ВИМІР ЕКОНОМІЧНОЇ ТЕОРІЇ І ПРАКТИКИ}

\section{(C) І. Г. Остапенко}

3 метою дослідження соиіокультурних детермінант економічної теорії та практики в запропонованій статті здійснюється аналіз прочесу становлення корпоративної культури як соціокультурного явища економічної сфери сучасного суспільства, його місия $і$ ролі в духовному та соціально-економічному житті соиіуму. Сочіально-економічна корпоративна культура визначається як причина і наслідок, функція і сутність соціальної суб'єктності корпорації, основний фактор безперервності ї̈ економічного $i$ соиіокультурного розвитку

Ключові слова: економічна теорія та практика, соціокультурні детермінанти, корпоративна культура, економічна дійсність

To investigate sociocultural determinants of economic theory and practice in the proposed article it is analyzed the process of formation of corporate culture as a sociocultural phenomenon of economic spheres of modern society, its place and role in the spiritual and socioeconomic life of society. Socioeconomic corporate culture is defined as cause and effect, function and nature of social subjectivity corporation, the main factor of continuity of its economic and sociocultural development

Keywords: economic theory and practice, sociocultural determinants, corporate culture, economic reality

\section{1. Вступ}

Сучасний період суспільного розвиту характеризується новими етико-моральними детермінантами, що визначають провідні тенденції культурного розвитку, пов'язані 3 наростаючою несумісністю економіко-технологічних та соціокультурних реалій ХХ століття з цінностями культури постмодерну. Культура новітньої доби в цілому і соціокультурні фактори економічного розвитку зокрема, на думку творця теорії постіндустріального суспільства Д. Белла, усвідомлюються як відмова від «модерну» або навіть його заперечення. Вона викликана неможливістю поєднати в нових умовах безособове, відірване від загальнолюдських цінностей виробництво і буття «економічної людини», засноване на раціоналізмі і ціннісному універсалізмі [1].

\section{2. Постановка проблеми}

Соціокультурна і економічна реальність сучасного суспільства відзначається формуванням нових аксіологічних орієнтирів, що спонукають до переходу від «філософії контракту», що служила фундаментом економічної кооперації індустріального виробництва, до філософії «спільної долі», яка передбачає соціально-відповідальне виробництво і спільну роботу суб'єктів економічної практики в ім'я досягнення соціально-значущої загальної мети. Філософія «спільної долі» $є$ новою світоглядною та ідеологічною концепцією найпотужніших економічних гравців світу, транснаціональних корпорацій та концернів світового значення. На думку Дж. К. Грейсона і К. О'Дейла, вона дозволяє співробітникам корпорації: по-перше, розуміти і розділяти проблеми своєї організації, по-друге, відчувати себе належними до неї, по-третє, бути впевненими, що їхні особисті інтереси нерозривно пов'язані з успіхом компанії і їі учасників, по-четверте, приймати на себе більш широку відповідальність, по-п'яте, швидко реагувати на нові запити і можливості [2]. 


\section{3. Аналіз літературних джерел}

Необхідно відзначити, що організаційна культура індустріального типу виробництва підготувала грунт для становлення корпоративної культури сучасного суспільства. Ю. А. Васильчук стверджує, що організаційна культура індустріальної епохи являла собою не тільки школу дисципліни праці, але була одночасно і школою масового вироблення моральної і політичної свідомості і дії, тобто вироблення соціально розвиненої активної особистості [3].

Умови індустріальної організації праці були найважчими, але багато в чому необхідним процесом дискредитації та відсіву асоціальної, індивідуалістичної особистості, утвердження в масі людей ідеалів справедливості, рівності і колективізму. Головне досягнення організаційної культури індустріальної епохи полягало в тому, що кваліфікована фізична праця стала ідеалом, що набув характеру соціальної цінності. Більш того, любов до праці та вироблення досвіду освоєння техніки формували елементи творчості у професійній діяльності людини. Організаційна культура не тільки викувала нового, фабрично-конвеєрного працівника, а й зруйнувала його колишню атомізацію, змусила мислити і діяти колективно, захищати свої права, апелюючи до совісті, законів і до держави. Конвеєрна праця, представляючи собою, важке насильство над особистістю, вимагаючи підпорядкування своїх бажань інтересам товариства, високого уявлення про потреби близьких, стала головним чинником становлення емоційно розвиненої особистості.

В історичній динаміці розвитку індустріальнопромислового капіталістичного суспільства організаційна культура постійно вдосконалювалася, знаходячи різні форми прояву. У процесі її еволюції виділяють три основних епохи: «наукового менеджменту», «людських відносин» і «техно-соціальних систем» [4].

Дж. В. Ньюстром та К. Девіс вважають, що зростання індустріального виробництва США, Західної Європи в 30-50 pр. ХХ століття викликало необхідність пошуку нових методів підвищення інтенсивності праці, вдосконалення організаційної культури. Дана обставина стимулювала розвиток «школи людських відносин», для якої було характерне звернення до працівника як до соціальної одиниці, як до сумлінної відповідальної людини. Життя його, поряд 3 економічними, визначалося також соціальними інтересами: свободою вибору, почуттям соціальної відповідальності, прагненням до самовираження [5]. Економічна організація починає розглядатись як соціальна система, найважливішим елементом якої $€$ працівник, а завданням культури організаційного управління є мотивація творчо активної природи людини, підвищення внутрішньої задоволеності кожного працівника.

Величезний вплив на поведінку співробітників має і колективна свідомість неформальних груп всередині виробничої організації. Неформальні групи представляють собою сукупність особистих і соціальних відносин, ніяк не обумовлених формальною організацією, що виникають спонтанно як результат взаємодії співробітників. У неформальних групах основну роль грають їх члени та їх взаємини, тоді як у формальних організаціях акцент робиться на офіційних ролях в термінах посадових прав і обов'язків індивідів. Неформальна влада звертається до людини як до особистості, тоді як формальна - до займаної співробітником посади. Д. Кракхард та Д. Хансон відзначають, що якщо формальна організація представляє собою скелет компанії, то неформальна - іiі центральну нервову систему, що забезпечує процес колективного мислення, діяльності і реакції її співробітників [6].

\section{4. Соціокультурні детермінанти економічної дійсності}

Отже, протягом минулого століття в системі організаційної економічної культури відбулася зміна зразків культурного регулювання професійних відносин заснованої на принципах: не примушувати - а пояснювати, стимулювати, підтримувати особисту ініціативу, культивувати толерантність, враховувати індивідуальні особливості особистості. Соціальний простір економічної індустріальної організації зазнав істотних змін - він став двовимірним, біполярним. У першому вимірі, який був відомим класичній школі Ф. Тейлора, М. Вебера і А. Файоля, людина розглядалася лише як функціонер. У другому вимірі, введеному гуманістичним напрямком, людина була представлена як особистість.

Отже, прогресивні, інноваційні зміни соціально-економічних відносин у країнах Заходу в другій половині XX століття сприяли становленню сучасного типу цивілізації і трансформації світоглядних орієнтирів особистості під впливом наступних факторів:

- по-перше, технічний прогрес звільнив багатьох від ручної праці характерної для індустріальної епохи;

- по-друге, рушійною силою розвитку суспільства стало виробництво інформаційного продукту, а не продукту матеріального;

- по-третє, зазнало змін співвідношення «вільного» $\mathrm{i}$ «робочого» часу;

- по-четверте, збільшилася кількість ролей, в яких кожна людина в сучасному суспільстві може спробувати себе;

- по-п'яте, як обов'язкова умова для здійснення професійної діяльності в рамках інформаційного суспільства та подальшого кар'єрного зростання середній рівень освіченості більшості людей підвищився.

Дана обставина викликала явище, яке А. Тоффлер озвучив як «ера зміщення влади», коли поступово розпадаються всі існуючі в світі владні структури і зароджуються нові. Високоосвічена людина не бажає покірно і беззаперечно підкорятися адміністрації, бути «слухняним гвинтиком» адміністративної машині. Вона все частіше вимагає у керівництва пояснень власних дій, ставить під сумнів своє місце і роль в ситуації соціальної ієрархії. У підсумку як керівник підприємства, так і провідний майстер, відзначають, що робітники вже не схильні беззаперечно виконувати накази. Вони вимагають їх пояснення та обгрунтування. Аналогічну поведінку спостерігають 
офіцери у солдатів, начальники силових структур у своїх підлеглих і особливо - викладачі у студентів.

Демократизація економічного життя веде до того, що від працівника, що формально не належить до категорії економічного менеджера, все більше вимагають володіння здібностями, що раніше вважалися винятковою прерогативою управлінців або організаторів виробництва. Дж. Ходжсон стверджує, що розмивання межі між менеджерами та працівниками економічної практики веде до «спрощення» традиційної ієрархії, розподілу відповідальності, яка раніше зосереджувалася на верхньому поверсі ієрархії, по всій організації. Тим самим послаблюється опір змінам: більш «плоскі» ієрархічні структури сприяють організаційному ускладненню.

Отже, збільшення інтенсивності залучення працівників у справи підприємства веде до скорочення розриву між рівнем політичної та економічної демократії, сприяє зняттю протиріччя між двома протилежними ролями людини: як повноправного громадянина в демократичному суспільстві і підлеглого у виробництві.

Отже, соціокультурний підхід до розвитку корпорації, виступає похідною від управлінської культури керівників та обумовлює синергетичний ефект в організаційному розвитку, тобто передбачає опору на «внутрішні» резерви суспільно-економічного розвитку, гармонійну єдність інтересів персоналу і економічної корпорації.

Сутнісною рисою сучасної економічної корпорації виступають партнерські відносини на рівні взаємодії інтересів двох сторін - керуючої і керованої: корпорація повинна збагачувати тих, хто 3 нею пов'язаний, а працюючі в ній робітники мають отримувати задоволення від своєї справи. У процесі становлення, розвитку і функціонування економічної корпорації формується специфічна ціннісно-нормативна система, відповідна корпоративним цілям, що враховує важливі для iї співробітників організаційні та корпоративні цінності. У діяльності сучасної корпорації актуалізується іiї соціальний компонент - людський капітал. Використовуючи засоби власної, корпоративної культури, корпорація забезпечує досягнення бажаного майбутнього шляхом реалізації системи ії внутрішніх, соціально значущих цінностей. Отже, формування і функціонування сучасних економічних корпорацій будується на базі їх відкритості та соціальної орієнтованості.

Кожен суб'єкт ринкових відносин вирішує самостійно питання не тільки внутрішньої організації, а й усієї сукупності зв'язків із зовнішньою групою осіб, що об'єднується спільністю професійних інтересів, як, наприклад, корпоративні інтереси. Від успішності вирішення цих проблем залежить ефективність роботи економічної корпорації.

Нова соціально-економічна управлінська парадигма істотно підвищує значущість корпоративної культури та етики. Викликано це тим, що корпоративна культура відіграє важливу роль в самоорганізації діяльності корпорації, її направленому розвитку. Корпоративна культура пов'язана зі сприйняттям соціальної реальності і регулює соціальну поведінку. Її зо- внішнім проявом є організаційна поведінка, через яку відбувається взаємодія з навколишнім світом, оцінка цінностей суспільства. Вона може гальмувати і стимулювати розвиток корпорації, впливати на розробку стратегії спрямованого розвитку і можливості їі реалізації. Отже, унікальність феномена корпоративної культури полягає в тому, що вона забезпечує досягнення бажаного майбутнього корпорації шляхом реалізації системи іiї внутрішніх цінностей.

Авторська позиція полягає в наступному. У контексті сучасної економічної дійсності доцільно артикулювати соціально-економічний та соціокультурний зміст поняття «соціально-економічна корпоративна культура», що являє собою не тільки оригінальну суміш цінностей, відносин, норм, звичок, традицій, форм поведінки і ритуалів, характерних для конкретної економічної організації, а й середовище самоактуалізаціїіі їі членів, властивий їй стиль відносин і поведінки в соціумі. У кожному з цих елементів простежується певна ступінь співвідношення між соціально-економічною корпоративною культурою і людиною, їх іманентна причетність одне до одного, яка необхідна як для існування людини, так і для культури всієї економічної корпорації. У цьому ключі доречним є вислів Ж.-П. Сартра про те, що культура нічого і нікого не рятує, та й не виправдовує. Культура створює людину, яка себе проектує в ній, впізнає в ній себе, і тільки в цьому критичному дзеркалі бачить вона свій вигляд.

Отже, соціально-економічна корпоративна культура сприяє створенню комфортного середовища життєдіяльності в колективі, як сума загальноприйнятих значень вона дозволяє членам групи жити i працювати у просторі, який вони однаково сприймають, вчиняти дії, характер яких зрозумілий всім іншим, регулювати соціальні та виробничі взаємодії в рамках прийнятої конвенції даної економічної організації. Людські ресурси, які у рамках корпоративної культури, об'єднані корпоративним духом, дозволяють істотно поліпшити базову характеристику сучасного виробництва - продуктивність праці. Соціальноекономічна корпоративна культура виступає як фактор, що інтегрує інтереси працівника і роботодавця за допомогою закріплення певних «правил гри», тобто очікуваних поведінкових установок для конкретної ситуації, поведінкових стереотипів, пов'язаних 3 виконанням конкретної роботи і дотриманням норм.

Необхідно відзначити, що соціально-економічна корпоративна економічна культура сучасного суспільства є практичним способом реалізації певної теоретичної надбудови - корпоративної філософії «спільної долі», де прописані соціально-значимі принципи економічної практики, зобов'язання суб'єктів економічної діяльності перед різними верствами суспільства, в тому числі і перед власними співробітниками. Корпоративна філософія є світоглядним фундаментом комунікативної та виробничої економічної діяльності будь-якого сучасного господарського організму. Етичні, правові, соціальні зобов'язання роблять організацію більш привабливою для зовнішньої аудиторії, з іншого боку, вони стверджують принцип командного підходу, єдиного корпоративно- 
го творчого духу, створення гуманістичного ставлення до кожного працівника на його робочому місці.

В рамках сучасної філософії корпоративної культури вирішенням проблеми відчуження в дихотомії «керуючі-керовані» стає модифікація внутрішніх рис праці, що формує характер самореалізації особистості як працівника, так і управлінця, в «робочий» час. У результаті відбувається збіг цінностей корпорації і персоналу в межах трудового процесу, а продуктивна діяльність стає важливим джерелом розвитку особистості, пов'язаним з максимізацією якісного поліпшення діяльності економічної організації в цілому.

\section{5. Результати дослідження}

Корпоративна культура сучасного суспільства формується під впливом корпоративної філософії корпоративної філософії як світоглядного фундаменту виробничої економічної діяльності, що полягає у інтегруванні етичних, правових та соціальних зобов'язань сучасного господарства перед власними працівниками $\mathrm{i}$ соціокультурною спільнотою яка забезпечує та підтримує розвиток соціально-орієнованого господарства.

Соціально-економічна корпоративна культура сучасного економічного виробництва грунтується на постійній роботі з персоналом, спрямованій не тільки на активізацію чисто професійних здібностей, підвищення кваліфікації та самовіддачі працівників, а й на гармонізацію відносин і психологічного клімату, що сприяють розвитку особистості. Зростає значення людських ресурсів, якість яких все частіше включається в «нематеріальний актив» корпорацій, і орієнтація на діалог і партнерство керівництва 3 персоналом. Економічне управління набуває «порадний» характер, а критика керівництва з боку підлеглих легалізується, набуває форми зворотного зв'язку.

Таким чином, на нашу думку, соціальноекономічна корпоративна культура сучасного суспільства являє собою складне багатогранне соціокультурне явище, засноване на цінностях «спільної долі», професіоналізму, самовираження і саморозвитку, співтворчості, співучасті особистості в діяльності сучасної економічної організації і суспільства, визначальний сенс існування корпорації, іiі ставлення до співробітників і суспільства. Соціально-економічна корпоративна культура являє собою не тільки оригінальну суміш цінностей, відносин, норм, звичок, традицій, форм поведінки і ритуалів, характерних для конкретної організації, а й середовище самоактуалізації і саморозвитку економічної структури, властивий їй стиль відносин і поведінки в соціумі. Соціально-економічна корпоративна культура виступає фактором інноваційних перетворень, які виводять на перше місце «людський ресурс», що набуває домінуюче значення і статус вимірювача економічного успіху сучасної корпорації.

\section{6. Висновки}

Соціально-економічна корпоративна культура $\epsilon$ способом вирішення протиріччя між суб'єктивністю економічної корпорації і суб'єктивністю ії учасників, що дозволяє їй, як самоорганізованій системі, долати точки біфуркації за допомогою вибору оптимальної стратегії управління економічною діяльністю. Вона виступає причиною і наслідком, функцією і сутністю соціальної суб'єктності корпорації, основним фактором безперервності її економічного і соціокультурного розвитку.

Соціально-економічна корпоративна культура сучасного суспільства $є$ практичним способом реалізації корпоративної філософії «спільної долі», що визначає соціально-значимі принципи економічної практики, зобов'язання суб'єктів економічної діяльності перед різними верствами суспільства, в тому числі і перед власними співробітниками. Унікальність феномена економічної корпоративної культури полягає в тому, що вона забезпечує досягнення бажаного майбутнього економічної корпорації шляхом реалізації системи їі внутрішніх цінностей.

\section{Література}

1. Белл, Д. Социальные рамки информационного общества [Текст] / Д. Белл; под ред. П. С. Гуревича. - Новая технократическая волна на Западе. - М.: Прогресс, 1986. - С. 330-342.

2. Грейсон, Д. Американский менеджмент на пороге XXI века [Текст] / Д. Грейсон, К. О'Делл; пер. с англ. - М.: Экономика, 1991. - 319 с.

3. Васильчук, Ю. А. Социальное развитие человека в XX веке [Текст] / Ю. А. Васильчук // Общественные науки и современность. - 2001. - № 1. - С. 5-26.

4. Шкаратан, О. И. Информационная экономика и пути развития [Текст] / О. И. Шкаратан // Мир экономики. -2002 . - Т. 11, № 3. - С. 44-61.

5. Ньюстром, Дж. В. Организационное поведение [Текст] / Дж. В. Ньюстром, К. Дэвис. - СПб.: Издательство Питер - Юг, 2000. - 296 c.

6. Krackhardt, D. Informal Networks: The Company Behind the Chart [Text] / D. Krackhardt, J. R. Hanson // Harvard Business Review. - 1993. - Vol. 71, Issue 4. - P. 100-115.

\section{References}

1. Bell, D.; Gurevicha, P. S. (Ed.) (1986). Social'nye ramki informacionnogo obshhestva. Novaja tehnokraticheskaja volna na Zapade. Moscow: Progress, 330-342.

2. Grejson, D., O'Dell, K. (1991). Amerikanskij menedzhment na poroge XXI veka. Moscow: Jekonomika, 319.

3. Vasil'chuk, Ju. A. (2001). Social'noe razvitie cheloveka v XX. Obshhestvennye nauki i sovremennost', 1, 5-26.

4. Shkaratan, O. I. (2002). Informacionnaja jekonomika i puti razvitija. Mir jekonomiki, 11 (3), 44-61.

5. N'justrom, Dzh. V., Djevis, K. (2000). Organizacionnoe povedenie. Sankt-Peterburg: Izdatel'stvo Piter - Jug, 296.

6. Krackhardt, D., Hanson, J. R. (1993). Informal Networks: The Company Behind the Chart. Harvard Business Review, 71 (4), 100-115.

Рекомендовано до публікації д-р філос. наук, професор Боринштейн Р. Є. Дата надходження рукопису 23.09.2015

Остапенко Ірина Григорівна, здобувач, кафедра філософії та соціології, Південноукраїнський національний педагогічний університет ім. К. Д. Ушинського, вул. Старопортофранківська, 26, м. Одеса, Україна, 65000 